\title{
THE IMPACT OF CALCIUM IONS ON COMMERCIALLY AVAILABLE B-GALACTOSIDASE
}

\author{
Kristine Zolnere ${ }^{1}$, Janis Liepins ${ }^{2}$, Inga Ciprovica ${ }^{1}$ \\ ${ }^{I}$ Department of Food Technology, Faculty of Food Technology, Latvia University of Agriculture, Rigas iela 22, Jelgava, Latvia, \\ e-mail: k.zolnere@gmail.com \\ ${ }^{2}$ Institute of Microbiology and Biotechnology, Latvia University, Jelgavas iela 1, Riga, Latvia
}

\begin{abstract}
Commercial lactose hydrolysing enzymes producers provide purchasers with information as optimal enzyme temperature and $\mathrm{pH}$, as well recommended amount of enzyme. However, there are also other indices in food substrate which might have impact on enzyme activity. The cations concentration in the substrate is the one of those. Whey is a dairy by-product with a relatively high $\mathrm{Ca}^{2+}$, $\mathrm{K}^{+}$and $\mathrm{Na}^{+}$ions concentration. These cations (especially $\mathrm{Ca}^{2+}$ ) are added in cheese making and remain in whey in comparatively large amounts. Moreover, $\mathrm{Na}^{+}$also remains in whey since salt is added for cheese grains salting. The aim of the study is to determine the impact of $\mathrm{Ca}^{2+}$ ions on commercially available $\beta$-galactosidase. The effect of $\mathrm{Ca}^{2+}$ ions on commercial $\beta$-galactosidase (NOLA Fit5500, Ha-Lactase 5200, Chr. HANSEN, Denmark; Lactozym ${ }^{\circledR}$ Pure 6500 L, Novozymes, Denmark) were tested. For investigation of the effect of $\mathrm{Ca}^{2+}$ ions on the $\beta$-galactosidase activity, chromogenic lactose substare - oNPG (2-nitrophenyl $\beta$-D-galactopyranoside; Sigma, Germany) was used, reactions were carried out at $\mathrm{pH} 6.6$, using $0.1 \mathrm{M}$ Tris- $\mathrm{HCl}$ buffer, and $\mathrm{Ca}^{2+}$ ions concentration range 5-50 mM. The enzymatic reactions were measured spectrophotometrically at $410 \mathrm{~nm}$ using Tecan 96-well plate reader (Tecan Group, Switzerland).The results imply, that $\mathrm{Ca}^{2+}$ ions alone do not have effect on lactose hydrolysis, moreover, in some they even stimulate it (NOLA Fit5500). The study results will help to precisely adjust the amount of commercially available enzymes to dairy substrates with high cations content.
\end{abstract}

Keywords: commercial $\beta$-galactosidase, lactose hydrolysis, calcium ions, enzyme kinetics.

\section{Introduction}

$\beta$-galactosidase $(\beta$-D-galactoside, galactohydrolases, EC 3.2.1.23) catalyses the cleavage of terminal galactosyl groups from the non-reducing ends of galactose containing carbohydrates. $\beta$-galactosidase is commercially relevant enzyme that is prevalently used for lactose hydrolysis in dairy industry (Carević et al., 2015).

Commercial $\beta$-galactosidase preparates are produced from bacterial and eukaryotic hosts: bacteria, yeasts, moulds, (Bacillus spp., Kluyveromyces spp., Aspergillus spp.) (Dagbagli, Goksungur, 2008; Panesar et al., 2006). Enzyme characteristics depends on the source of aminoacids composition, active site and presence or absence of allosteric regulatory sites, $\mathrm{pH}$ - and thermal- optimum and stability (Mlichová, Rosenberg, 2006).

Various substances can alter enzyme catalytic activity activating or inhibiting it; metal ions and their complexes are play important role in enzyme structure stabilization and/or activation or inhibition of the reaction. If metal ions are required by enzyme to maintain its stable, native state, it is called as metalloenzyme whereas if metal ions require only during catalytic activity enzymes are called "metal activated enzymes" (Zohra et al., 2016).

Calcium ions $\left(\mathrm{Ca}^{2+}\right)$ are known as inhibitor for many $\beta$-galactosidases, but for some $\beta$-galactosidase act also as activator when added in concentrations of $1-10 \mathrm{mM}$, which also conform to concentrations of free calcium in milk or whey. This property can be advantageous for applications in lactose hydrolysis processes directly in milk or when using lactose-rich substrates based on whey with high level of $\mathrm{Ca}^{2+}$ in solution. (Juajun et al., 2011).

The aim of this paper is to determine the impact of $\mathrm{Ca}^{2+}$ ions on commercially available $\beta$-galactosidase.

\begin{abstract}
Materials and Methods
Chemicals and enzymes

Three commercial preparates of $\beta$-galactosidase were used in the study: NOLA Fit5500 and Ha-Lactase 5200 (Chr.HANSEN, Denmark) and Lactozym® Pure 6500 L (Novozymes, Denmark), NOLA Fit5500 is derived from Bacillus licheniformis, other two enzymes are of Kluyveromyces lactis origin. All enzymes were stored at $4{ }^{\circ} \mathrm{C}$ and remained fully active throughout the study All reagents used: $\mathrm{MgCl}_{2}, \mathrm{CaCl}_{2}$, p-nitrophenol, 2-nitrophenyl-galactoside (o-NPG) were purchased from Sigma (Germany).

Research was carried out to determinate $\mathrm{Ca}^{2+}$ influence at different concentrations $(5-50 \mathrm{mM})$ on $\beta$-galactosidase activity of three different, commercially available, enzyme preparates.
\end{abstract}

Enzymatic assay

$\beta$-galactosidase activity was determined using chromogenic substrate o-NPG by monitoring the increasing of absorbance at $410 \mathrm{~nm}$.

Enzyme. Each commercial $\beta$-galactosidase were diluted with distillate water for optimal concentration: NOLA Fit5500 with average activity $5500 \mathrm{BLUg}^{-1}$ (1:16); HaLactase 5200, with average activity $5200 \mathrm{NLU} \mathrm{g}^{-1}$ (1:2); and Lactozym ${ }^{\circledR}$ Pure6500 L with average activity 6500 LAU $\mathrm{g}^{-1}$ (1:4). Activity units of commercial $\beta$-galactosidases are defined differently by each producer.

Substrate. All reactions were performed in $0.1 \mathrm{M}$ Tris$\mathrm{HCl}$ buffer, $\mathrm{pH} 6.6$, containing $1 \mathrm{mM} \mathrm{MgCl}_{2}$ and o-NPG concentration in the range from 1.25 to $7.25 \mathrm{mM}$. To asses $\mathrm{Ca}^{+2}$ effect on enzyme activity we used $\mathrm{CaCl}_{2}$ in concentrations 5-50 mM. The measured activities were compared with the activity of the enzyme without added $\mathrm{Ca}^{+2}$ under the same conditions. 
Enzymatic reactions were measured using 96-well plate in multimode plate reader Infinite $200 \mathrm{M}$ Pro (Tecan Group, Switzerland). Total reaction volume was $200 \mu \mathrm{L}$ per well, all reactions were started by adding $10 \mu \mathrm{L}$ of enzyme.

\section{Calibration}

o-nitrophenol is hydrolysis product of oNPG. To quantify its production in multimode reader was set up calibration curve by using pure o-nitrophenol solution in the range $0-3.15 \mathrm{mM}$.

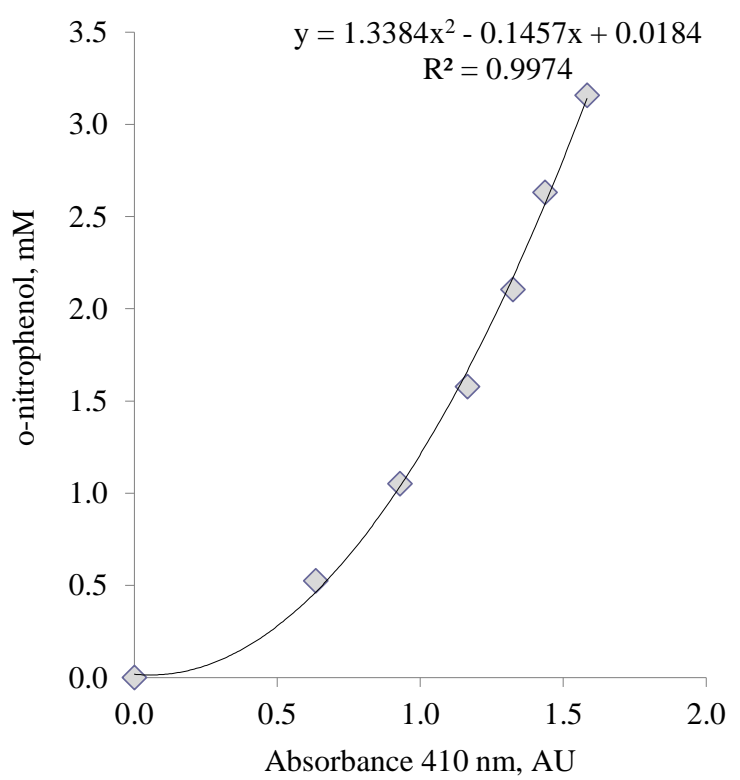

Figure 1. Calibration curve of o-nitrophenol

We found $2^{\text {nd }}$ order polynome approximation to fit our data. By the calibration curve of o-nitrophenol (see Figure 1), were calculated reaction kinetics.

Data analysis

Data were treated by Microsoft Office 2016 Excel.

\section{Results and Discussion}

$\mathrm{Ca}^{+2}$ is the major cation in bovine milk with a total concentration up to $25 \mathrm{mM}$ (Tanaka et al., 2011). For cheese production, $\mathrm{Ca}^{+2}$ is added in concentrations 0.2-0.4 M (Abdalla, Ahmed, 2010; Landfeld et al., 2002; Mehaia, 2006). In whey, cheese by-product, $\mathrm{Ca}^{+2}$ concentration can reach 2.0-6.0 mM (Hill et al., 1985; Theoleyre, Gula, 2004; Wong et al. 1978). Due to $\mathrm{Ca}^{+2}$ impact potential and its wide range of concentrations in milk and by-products, it is of practical importance to evaluate $\mathrm{Ca}^{+2}$ impact on $\beta$-galactosidases activity at concentrations up to $50 \mathrm{mM}$.

\section{Enzyme kinetic constants}

To assess $\mathrm{Ca}^{+2}$ impact on lactose hydrolysis we studied changes of enzymatic kinetic parameters $\mathrm{V}_{\max }$ (velocity) and $\mathrm{K}_{\mathrm{M}}$ (Michaelis-Menten constant). We used classical Michaelis-Menten type kinetics to describe enzyme activity. For $\mathrm{K}_{\mathrm{M}}$ and $\mathrm{V}_{\max }$ measurement, we used reciprocal graphical representation of enzymatic kinetics (Lineweaver-Burk plots) (Güleç et al., 2010). $\mathrm{K}_{\mathrm{M}}$ is equal to the substrate concentration at which the reaction rate is half its maximal value (Atrooz et al., 2016).

To compare the results, all enzyme $\mathrm{V}_{\max }$ and $\mathrm{K}_{\mathrm{M}}$ values were expressed as fold change calculated against respective enzyme kinetic values without $\mathrm{Ca}^{+2}$ addition. Results are presented in Table 1.

Table 1

$\mathrm{Ca}^{2+}$ effect on commercial $\beta$-galactosidase $V_{\max }$ and $K_{m}$

\begin{tabular}{|c|c|c|c|c|c|c|}
\hline \multirow{2}{*}{$\begin{array}{c}\mathrm{Ca}^{+2}, \\
\mathbf{m M}\end{array}$} & \multicolumn{2}{|c|}{$\begin{array}{l}\text { Lactozym }{ }^{\circledR} \\
\text { Pure } 6500 \text { L }\end{array}$} & \multicolumn{2}{|c|}{$\begin{array}{c}\text { NOLA } \\
\text { Fit5500 } \\
\end{array}$} & \multicolumn{2}{|c|}{$\begin{array}{c}\text { Ha-Lactase } \\
5200 \\
\end{array}$} \\
\hline & $\mathrm{V}_{\max }$ & $\begin{array}{c}\mathbf{K}_{\mathbf{M}} \\
\%\end{array}$ & $\begin{array}{l}\mathbf{V}_{\max }, \\
\%\end{array}$ & $\begin{array}{c}\mathbf{K}_{\mathrm{M}} \\
\%\end{array}$ & $\mathrm{~V}_{\max }$, & $\mathrm{K}_{\mathrm{M}}, \%$ \\
\hline 0 & 1.000 & 1.000 & 1.000 & 1.000 & 1.000 & 1.000 \\
\hline 5 & 1.022 & 1.421 & 0.847 & 0.889 & 0.011 & 95.071 \\
\hline 10 & 0.777 & $* N D$ & 0.836 & 0.896 & 0.011 & 88.906 \\
\hline 15 & 0.834 & $*$ ND & $*$ ND & 0.782 & 0.011 & 91.792 \\
\hline 30 & 0.776 & $* \mathrm{ND}$ & 0.916 & 0.926 & 0.011 & 89.913 \\
\hline 50 & 0.791 & $* \mathrm{ND}$ & 0.859 & 0.909 & 0.011 & 99.612 \\
\hline
\end{tabular}

$\mathrm{V}_{\max }$ and $\mathrm{K}_{\mathrm{M}}$ values are presented as fold change when normalised to reaction without $\mathrm{Ca}^{2+}$.

As seen in Table 1, the results showed that commercial $\beta$-galactosidases preparates NOLA Fit5500 and Lactozym ${ }^{\circledR}$ Pure $6500 \mathrm{~L}$ were rather insensitive to increasing $\mathrm{Ca}^{2+}$ concentration, whereas Ha-Lactase 5200 exhibit strong inhibition. Analysing NOLA Fit5500 enzyme activity by changing $\mathrm{Ca}^{2+}$ concentration, results showed that oNPG hydrolysis stayed almost the same as it was for the reaction without $\mathrm{Ca}^{2+}$ addition. Enzyme kinetic parameters $-\mathrm{K}_{\mathrm{M}}$ and $\mathrm{V}_{\max }$ was the same up to $30 \mathrm{mM}$ of $\mathrm{Ca}^{2+}$. Lactozym ${ }^{\circledR}$ Pure $6500 \mathrm{~L}$ showed the highest results at $\mathrm{Ca}^{2+}$ concentration $5 \mathrm{mM}$ where $\mathrm{K}_{\mathrm{M}}(1.421 \%)$ and $\mathrm{V}_{\max }(1.022 \%)$. While at $\mathrm{Ca}^{2+}$ concentration up to $10 \mathrm{mM}$ enzyme $\mathrm{V}_{\max }$ decreased to $0.777 \%$ and till $50 \mathrm{mM}$ stayed in similar condition.

Several researches have been made to analyse various monovalent and divalent cations impact on $\beta$-galactosidase activity. In the case of $\beta$-galactosidase from Bacillus licheniformis, results show that $\mathrm{Ca}^{2+}$ at concentrations of $1-10 \mathrm{mM}$ together with $\mathrm{Na}^{+}$ $(1-10 \mathrm{mM})$ can activate $\beta$-galactosidase (Juajun et al., 2011).

Banerjee and co-authors (1982) examined the effect of different metal ion concentrations $\left(\mathrm{Mg}^{2+}, \mathrm{Ca}^{2+}\right)$ on native and immobilized cells of $\beta$-galactosidase producing by Saccharomyces anamensis, the highest activity was at $2.35 \mathrm{mM}$ concentration. Furthermore it was established that at higher $\mathrm{Ca}^{2+}$ concentration the enzyme activity remains unchanged (Banerjee et al., 1982).

We have summarised information from some literature sources on cationic effects on $\beta$-galactosidases from various organisms (Table 2). As seen in Table $2, \mathrm{Ca}^{2+}$ can be as $\beta$-galactosidase activator or inhibitor.

A wide range of metal ions are known to influence the activity of $\beta$-galactosidase (Pandey et al., 2017). The bacterial cell wall contains many types of cations including $\mathrm{Mg}^{2+}, \mathrm{Ca}^{2+}, \mathrm{Na}^{+}$, and $\mathrm{K}^{+}$(Sahalan et al., 2013). 
Cation effects on $\beta$-galactosidases

\begin{tabular}{|c|c|c|c|}
\hline Source of enzyme & Activator & Inhibitor & References \\
\hline Aeromonas caviae & $\mathrm{Ca}^{2+} ; \mathrm{Mg}^{2+}$ & - & (Karunakaran \& Devi, 1994) \\
\hline Kluyveromyces lactis & $\mathrm{K}^{+} ; \mathrm{Mg}^{2+}$ & $\mathrm{Ca}^{2+} ; \mathrm{Na}^{+}$ & (Otieno, 2010) \\
\hline Lactobacillus reuteri & $\mathrm{K}^{+} ; \mathrm{Na}^{+} ; \mathrm{Mn}^{2+}$ & $\mathrm{Fe}^{2+} ; \mathrm{Ca}^{2+} ; \mathrm{Cu}^{2+}$ & (Nguyen et al., 2006) \\
\hline Bacillus licheniformis & $\mathrm{Ca}^{2+} ; \mathrm{Mn}^{2+} ; \mathrm{Mg}^{2+}$ & $\mathrm{Cu}^{2+} ; \mathrm{Zn}^{2+} ; \mathrm{Fe}^{2+}$ & (Akcan, 2011) \\
\hline Kluyveromyces fragilis & $\mathrm{Mn}^{2+}, \mathrm{Mg}^{2+}, \mathrm{K}^{+}$ & $\mathrm{Ca}^{2+}$ & (Mlichová \& Rosenberg, 2006) \\
\hline Amygdalus communis & $\mathrm{Ca}^{2+} ; \mathrm{Mn}^{2+}$ & $\mathrm{K}^{+} ; \mathrm{Na}^{+}$ & (Pal et al., 2013) \\
\hline Saccharomyces anamensis & $\mathrm{Ca}^{2+} ; \mathrm{Mn}^{2+}$ & - & (Banerjee et al., 1982) \\
\hline
\end{tabular}

Bacterial $\beta$-galactosidase can be activated by $\mathrm{Ca}^{2+}$, while yeast or mould $\beta$-galactosidase for most of the cases inhibited (see Table 2) (Mlichová, Rosenberg, 2006). In some cases, $\mathrm{Ca}^{+2}$ and $\mathrm{Mg}^{+2}$ is absolute necessity for $\beta$-galactosidase activity of Aeromonas cauiae (Karunakaran, Devi, 1994). Instead Kumar and coauthors (2015) stated that metal ion $\mathrm{Ca}^{2+}$ and $\mathrm{Na}^{+}$in concentration of 10-30 mM did not affected the Serratia quinivorans $\beta$-galactosidase activity (Kumar et al., 2015).

It should be noted that nowadays the commercial $\beta$-galactosidase is mainly produced by Kluyveromyces lactis (You et al., 2017) such as Lactozyme $2600 \mathrm{~L}$, GODO-YNL2, Ha-Lactase 5200, Lactozym® Pure $6500 \mathrm{~L}$ and Maxilact ${ }^{\circledR}$ LX5000 which is used in industrial field.

\section{Conclusions}

The results imply, that $\mathrm{Ca}^{2+}$ alone does not have effect on lactose hydrolysis by NOLA Fit5500 and Lactozym ${ }^{\circledR}$ Pure 6500 L $\beta$ galactosidases, enzyme kinetic parameters $-\mathrm{K}_{m}$ and $\mathrm{V}_{\max }$ at different $\mathrm{Ca}^{2+}$ concentrations stayed almost the same as it is for the reaction without $\mathrm{Ca}^{2+}$ addition. Ha-Lactase 5200 $\beta$-galactosidase is strongly inhibited by $\mathrm{Ca}^{2+}$, this preparate would not be recommended to use for lactose hydrolysis in media with a high concentration of $\mathrm{Ca}^{2+}$. Future research should be done to find out if $\mathrm{Ca}^{2+}$ together with other cations present in whey has additive effects on $\beta$-galactosidase activity.

\section{References}

1. Abdalla M. O. M., Ahmed O. I. (2010) Effect of heat treatment, level of sodium chloride, calcium chloride on the chemical composition of white cheese. Research Journal of Animal and Veterinary Sciences, Vol. 5, p. 69-72.

2. Akcan N. (2011) High level production of extracellular $\beta$ galactosidase from Bacillus licheniformis ATCC 12759 in submerged fermentation. African Journal of Microbiology Research, Vol. 5 (26), p. 4615-4621.

3. Atrooz O. M., Abukhalil M. H., Alrawashdeh I. M. (2016) Characterization of $\beta$-galactosidase in the Crude Plant Extract of Artemisia judaica L. in Presence and Absence of Some Heavy Metals Characterization of $\beta$-galactosidase in the Crude Plant Extract of. American Journal of Life
Sciences, Vol. 4 (5), p. 99-105.

4. Banerjee, M., Chakrabarty, A., \& Majumdar, S. K. (1982). Immobilization of yeast cells containing. Biotechnology and Bioengineering, Vol. 24 (8), p. 1839-1850.

5. Carević M., Vukašinović-Sekulić M., Grbavčić S., Stojanović M., Mihailović M., Dimitrijević A., Bezbradica D. (2015) Optimization of $\beta$-galactosidase production from lactic acid bacteria. Hemijska Industrija, Vol. 69 (3), p. 305-312.

6. Dagbagli S., Goksungur Y. (2008) Optimization of Bgalactosidase production using Kluyveromyces lactis NRRL Y-8279 by response surface methodology. Electronic Journal of Biotechnology, Vol. 11 (4), p. 11-12.

7. Güleç H. A., Gürdaş S., Albayrak N., Mutlu M. (2010) Immobilization of Aspergillus oryzae $\beta$-galactosidase on low-pressure plasma-modified cellulose acetate membrane using polyethyleneimine for production of galactooligosaccharide. Biotechnology and Bioprocess Engineering, Vol. 15, No.6, p. 1006-1015.

8. Hill A. R., Irvine D. M., Bullock D. H. (1985) Buffer Capacity of Cheese Wheys. Journal of Food Science, Vol. 50 (3), p. 733-738.

9. Juajun O., Nguyen T.-H., Maischberger T., Iqbal S., Haltrich D., Yamabhai M. (2011) Cloning, purification, and characterization of $\beta$-galactosidase from Bacillus licheniformis DSM 13. Applied Microbiology and Biotechnology, Vol. 89 (3), p. 645-654.

10. Karunakaran T., Devi B. G. (1994) Factors influencing Pgalactosidase activity of Aeromonas caviae. Journal of Basic Microbiology, Vol. 34, p. 245-252.

11. Kumar T., Sourirajan A., Dev K. (2015) Isolation and Characterization of Psychrotolerant Serratia Quinivorans Strains Secreting $\beta$-D-galactosidase. Universal Journal of Microbiology Research, Vol. 3 (1), p. 1-9.

12. Landfeld A., Novotná P., Houška M. (2002) Influence of the amount of rennet, calcium chloride addition, temperature, and high-pressure treatment of the course of milk coagulation. Czech Journal of Food Sciences, Vol. 20 (6), p. 237-244.

13. Mehaia M. (2006) Manufacture of fresh soft white cheese (Domiati type) from dromedary camel's milk using ultrafiltration process. Journal of Food Technology. Vol. 4 (3), p. 206-212.

14. Mlichová Z., Rosenberg M. (2006) Current trends of $\beta$-galactosidase application in food technology. Journal of Food and Nutrition Research, Vol. 45 (2), p. 47-54.

15. Nguyen T.-H. Splechtna B., Steinbock M., Kneifek W., Lettner H. P., Kulbe K. D., Haltrich D. (2006) Purification and Characterization of Two Novel $\beta$-galactosidases from 
Lactobacillus reuteri. Journal of Agricultural and Food Chemistry, Vol. 54, p. 4989-4998.

16. Otieno D. O. (2010) Synthesis of $\beta$-galactooligosaccharides from lactose using microbial $\beta$-galactosidases. Comprehensive Reviews in Food Science and Food Safety, Vol. 9 (5), p. 471-482.

17. Pal A., Lobo M., Khanum F. (2013) Extraction, Purification and Thermodynamic Characterization of Almond (Amygdalus communis) $\beta$-galactosidase for the Preparation of Delactosed Milk. Food Technology and Biotechnology, Vol. 51 (1), p. 53-61.

18. Pandey A., Negi S., Soccol C. R. (2017) Current developments in biotechnology and bioengineering: production, isolation and purification of industrial products. Amsterdam: Elsevier. 886 p.

19. Panesar P. S., Panesar R., Singh R. S., Kennedy J. F., Kumar H. (2006) Microbial production, immobilization and applications of $\beta$-D-galactosidase. Journal of Chemical Technology \& Biotechnology, Vol. 81 (4), p. $530-543$.

20. Sahalan A. Z., Ahuberziz A. H. A., Lian,H. H., Ghani M. K. A. (2013) Divalent cations $\left(\mathrm{Mg}^{2+}, \mathrm{Ca}^{2+}\right)$ protect bacterial outer membrane damage by polymyxin B. Sains Malaysiana, Vol. 42 (3), p. 301-306.
21. Tanaka M., Suzuki T., Kotb S., Kamiya Y. (2011) Relation of calcium activity in milk and milk production of holstein cows in hot season. Asian-Australasian Journal of Animal Sciences, Vol. 24 (10), p. 1372-1376.

22. Theoleyre M.A., Gula F. (2004) Purification of food streams by combining ion exchange and membranes technologies: application of decalcification in the whey industry. In: International Conference Engineering and Food Purification, ICEF9-2004, France, p. 1-6.

23. You S., Zhang J., Yin Q., Qi W., Su R., He, Z. (2017) Development of a novel integrated process for coproduction of $\beta$-galactosidase and ethanol using lactose as substrate. Bioresource Technology, Vol. 230, p. 15-23.

24. Wong N. P., LaCroix D. E., McDonough F. E. (1978) Minerals in whey and whey fractions. Journal of Dairy Science, Vol. 61 (12), p. 1700-1703.

25. Zohra R. R., Qader S. A. U., Pervez S., Aman A. (2016) Influence of different metals on the activation and inhibition of $\alpha$-amylase from thermophilic Bacillus firmus KIBGE-IB28. Pakistan Journal of Pharmaceutical Sciences, Vol. 29, p. 1275-1278. 